\title{
The History of the Portuguese Aviation- A Summary
}

\author{
Fernando M. S. P. Neves, Jorge M. M. Barata, André R. R. Silva \\ Aerospace Sciences Department, Universidade da Beira Interior, Covilhã, Portugal \\ Email: fernandomneves@gmail.com
}

How to cite this paper: Neves, F.M.S.P., Barata, J.M.M. and Silva, A.R.R. (2016) The History of the Portuguese Aviation-A Summary. Open Journal of Applied Sciences, 6, 667-695.

http://dx.doi.org/10.4236/ojapps.2016.610063

Received: July 14, 2016

Accepted: September 23, 2016

Published: September 27, 2016

Copyright $\odot 2016$ by authors and Scientific Research Publishing Inc. This work is licensed under the Creative Commons Attribution International License (CC BY 4.0).

http://creativecommons.org/licenses/by/4.0/

\begin{abstract}
This article is intended as a summary of a new area of study on the History of the Portuguese Aeronautics and Aerospace and addresses issues such as: the forthcoming of the aircraft at Portugal, its military and civilian use; the scope of early days concerning Portuguese intercontinental flights and their authors; the development of air navigation devices by Portuguese inventors in the 1920s and 30s; the Aeronautics industry and the need to develop expertise in Aeronautical/Aerospace Engineering in Portugal during the centuries XX and XXI.
\end{abstract}

\section{Keywords}

Admiral Coutinho Precision Sextant, Gago Coutinho, Sacadura Cabral, Sarmento Beires, Aeronautics, Aerospace Engineering, UBI, IST, AFA

\section{(c) (i) Open Access}

\section{Background Introduction}

The aviation education and training has of similar age the first powered flight of the Wright Brothers. However, it should be pointed out that the Wright Brothers controlled flight in a heavier-than-air machine would not be possible without the previous studies and experiments of others before them like Sir George Cayley, Otto Lilienthal, or Samuel Langley. In most cases, aviation education and training was an evolution of a well-established military command like in the United States, United Kingdom or Portugal. In some countries the military training was separated from the classical university teaching and the civil counterpart took several years to start. Nevertheless, the civil education in a regular basis has also started in the early decades of the $20^{\text {th }}$ century. By early 1903 the echoes of the Wright Brother's flights attempts dominated the conversations of the more enthusiastic audiences at France. With the Octave Chanute's arrival to Paris in April 1903 and with a Lecture that he gave at the Aéro-Club de France con- 
cerning their gliders as well as the Wright brothers gliders, contributed greatly to a further more numerous and enthusiastic audience. France immediately began a bustle construction of gliders and also gliders with engines adaptations. However, it was a dedicated sportsman, Santos Dumont that gave to France the most unbridled enthusiasm and excitement moments; with the airplane 14-bis called "Bird of Prey" on 23 October 1906, a flight witnessed by the European Press and French Aviation authorities; on that day, Dumont wins the 3,000 French francs of the Ernest Archdeacon Prize, flying his 14-bis biplane long a distance of nearly 50 meters (164 feet). Portugal became immediately anxious by that ardent enthusiasm aroused by the airplane appearing [1] [2].

\section{Aeronautics Introduction}

\subsection{Foundation of the Aero Clube De Portugal}

From 10 July to 17 October 1909 it was held the first aeronautical exhibition at Frankfurt and by the Portuguese Minister of Army orders, Lieutenant Engineering Pedro Fava Ribeiro de Almeida was sent to attend that event. During that journey he visited some aero clubs, which led him to assemble a group of friends with the idea to organize a similar association at Portugal. On December 11, 1909 with 17 members, mostly Engineering Officers he founded the Aero Clube de Portugal [Aero Club of Portugal], with a main purpose to co-ordinate the future Portuguese Aviation role [3].

\subsection{Foundation of the Military Aviation at Portugal}

Alongside the development of the Aviation in Europe, especially France, where Military Aviation was established in 1909 with the intent to cooperate with the Army, had generated some purpose interest at Portugal, which enthusiastically led Dr. Antonio José de Almeida in 1912 to defend in the Republic Parliament, the foundation of Military Aviation at Portugal aimed to supporting both the Army and the Navy. Amidst the growing enthusiasm that the airplane was awake at Portugal, it led to the emergence of the first subscriptions in order to the purchase of several flying apparatus designed for the Army. By the end of 1912, Portugal had already purchased three apparatus: a biplane Avro 500 from England, a biplane Maurice Farman MF4 and a monoplane Deperdussin type $B$ both from France. On January $28^{\text {th }} 1913$, Portugal becomes the $18^{\text {th }}$ Country affiliated to the Fédération Aéronautique Internationale-FAI (International Aeronautical Federation). On 8 February 1913 it was named a Commission of Army and Navy Officers with the purpose to study and to consolidate the main bases for the organization of a Flight School with military character and to choose the area as well as the airplanes to acquire. Still in 1913, this Committee presented a report with some recommendations that leaded to a Law, dated on the $14^{\text {th }}$ May 1914, creating officially a School of Military Aeronautics. It was inaugurated in August $1^{\text {st }} 1916$ with the designation of Escola Militar de Aviação (Military Aviation School), regarding both Ballooning and Aviation Services (Figure 1). It was also built a Parque de Material Aeronáutico (Aeronautical Material Park) in order to support the Military Aeronautics operations. On February 5, 1920, the Aviation Military School was transferred to another location: Granja do 


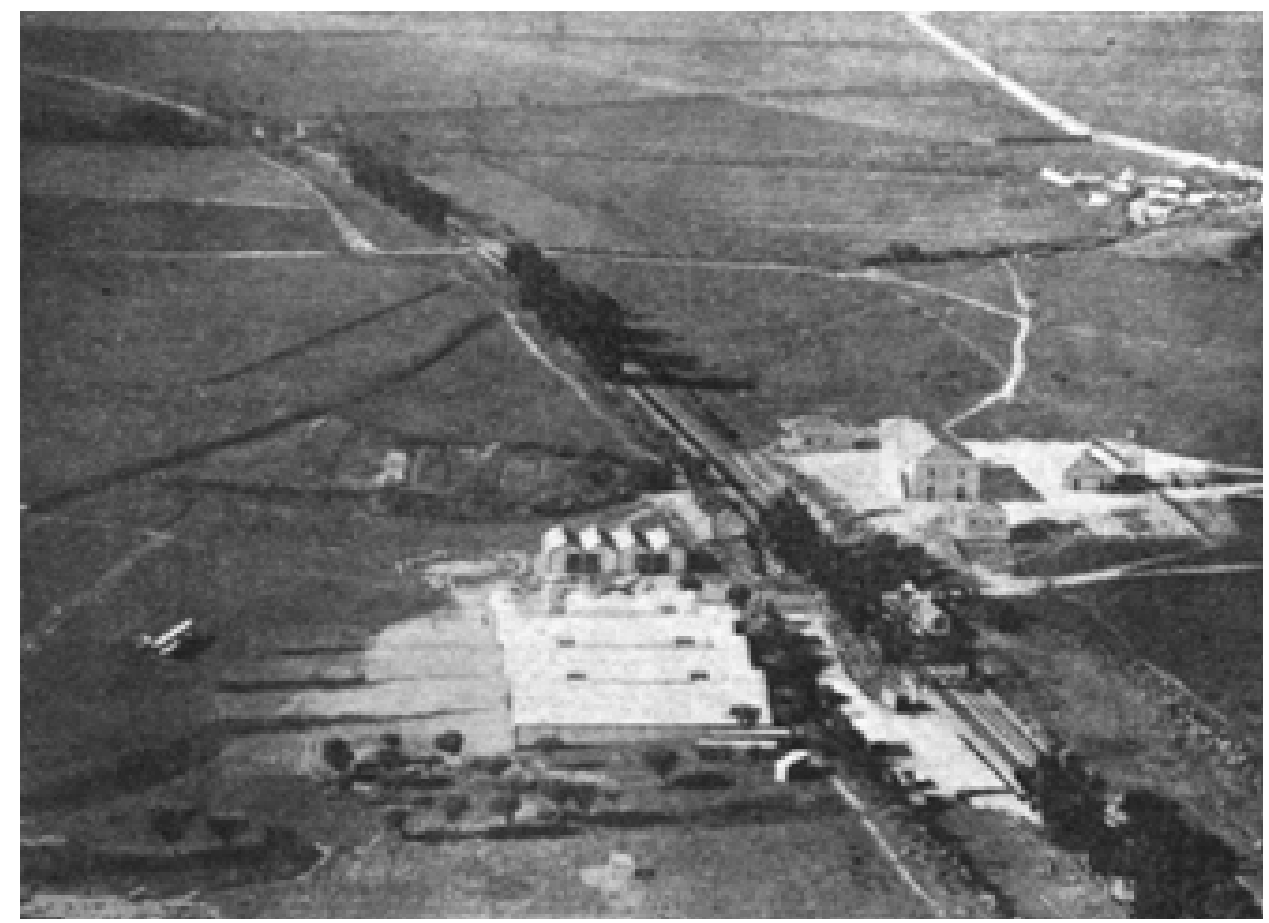

Figure 1. Aerial view of the Military School Aviation at Vila Nova da Rainha [1].

Marquês, Sintra. The first pilot course flying lessons in Portugal began on November $2^{\text {nd }} 1916$, including a section of conventional airplanes and a section of Navy seaplanes. The main objectives assigned to this School were to: instruct the staff pilots, mechanics and more specialists in the aeronautical service; repair and preserve all instructional material; study all matters related to the aeronautical service, developing the appropriate regulations and proposing amendments to the same service as well as aeronautical charts mapping [1].

Major Pedro Fava Ribeiro de Almeida, in his Portuguese engineer quality, was the mechanics chief and supervises the School factory; he had as his assistant a French mechanical engineer Wilfart, who introduced and built the first engine test bench at Portugal. The instructor pilot and director of instruction was Artur de Sacadura Freire Cabral, just arrived from France, where he had obtained his "brevet" at Centre $d$ Aviation Militaire de Chartres. After its first pilot license, he went to the École de P Aviation Maritime de Saint-Raphael (Maritime Aviation Scholl of Saint Raphael) and made a specialization in seaplanes. He also attended at various training Schools and made a specialization in faster airplanes, flying the Blériot and Caudron G3 models in the École $d$ Aviation de Buc (Aviation School of Buc). On May $10^{\text {th }} 1917$ the Military Aviation School delivers its first 13 pilot diplomas. In 1918 the Aeronautical Material Park was actually created by Decree-Law $n^{\text {er }} 4529$ of June $29^{\text {th }} 1918$ and was transferred to a different location: Alverca. From 1925 to 1928 the Military Aviation School delivers its first 4 civil pilot diplomas: Carlos Eduardo Bleck, Manuel Vasques, Sousa Santos e Maria de Lurdes Sá Teixeira. In 1928, the Military Aviation School was renamed Escola Militar de Aeronáutica (School of Military Aeronautics). On June 5, 1930 it was autho- 
rized the Escola de Aviação Civil (Civil Aviation School) built beside the School of Military Aeronautics [1] [3].

\subsection{First Flight from Europe to the South Atlantic-1922}

One day before the arrival of Lieutenant Albert C. Read to Lisbon, Sacadura Cabral handed a document to the Minister of the Navy in which he proposes himself to hold the Crossing Lisbon to Rio de Janeiro with the purpose of the progress of Portuguese Aviation and as a way of strengthen the ties of friendship between Portugal and Brazil. The Ministry of Navy in accordance with the document received from the Government on June $6^{\text {th }} 1919$ (Portaria de 6 de Junho de 1919), instructed Sacadura Cabral to organize the attempt of Lisbon-Rio de Janeiro crossing. The same Ministry also managed that Foreign Affairs had appointed Sacadura Cabral as Adido Aeronáutico near the Portuguese's Legacies at London, Paris and Washington. Gago Coutinho and Sacadura Cabral started the first flight across the South Atlantic Journey at the Bom Sucesso Naval Air Station in the Tagus River near the Belém Tower in Lisbon, at 07:00 on March 30, 1922. The used seaplane Fairey III D "Lusitânia” was equipped with an artificial horizon precision sextant for aeronautical use; a revolutionary invention at the time according to the Portuguese Navy Museum, testing the horizon was one of the main reasons for the flight [4]-[7]. Figure 2 illustrates Portuguese navigators, the used sextant and the seaplane "Lusitânia".
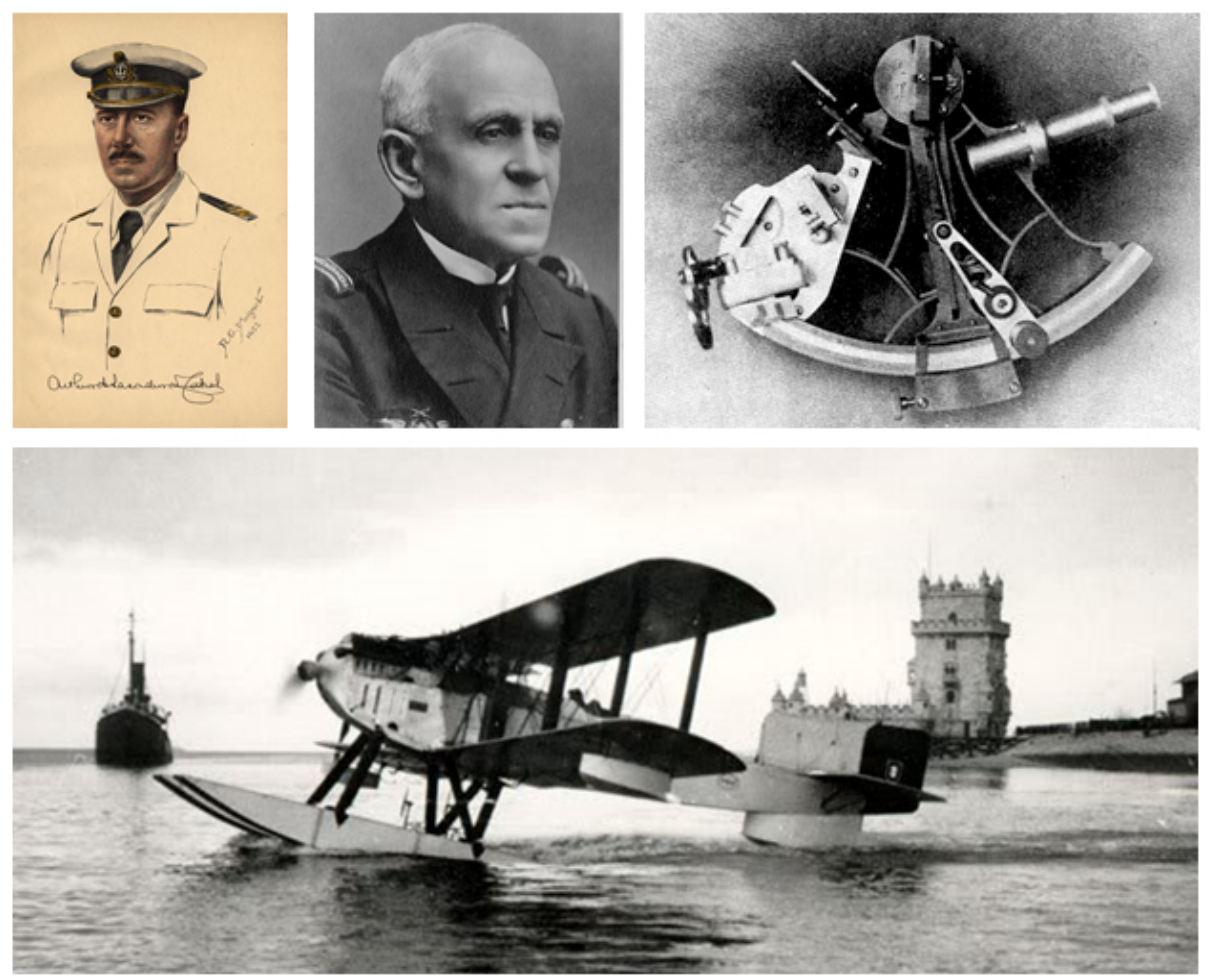

Figure 2. Portraits of Sacadura Cabral (above, left) and Gago Coutinho (above, center); picture of precision sextant (above, right); and the departure of the seaplane "Lusitânia" starting the First Flight from Europe to the South Atlantic (bottom). 
Despite this journey had lasted 79 days to cross South Atlantic Ocean, their flight time was only 62:26 minutes, and they've flown 8,383 nautical miles, using 3 different hydroplanes christened: Lusitânia, Pátria and Santa Cruz. The journey ended in June, on the $17^{\text {th }}$, at Rio de Janeiro, where they were enthusiastically received as heroes. They have just crossed the South Atlantic Ocean for the first time, with only internal means of navigation (the Admiral Coutinho Precision Sextant). This event is an important landmark in aeronautical history and marks the use of sextant in air navigation for the very first time. Besides, it reflects the courage and bravery of Portuguese in conquering the airspace [4].

\subsection{First Aerial Journey from Portugal to Macau-1924}

In 1923 Gago Coutinho and Sacadura Cabral were contemplating to perform an Around the World Flight. However, Sacadura died in 1924, while piloting an airplane acquired for the circumnavigation voyage. Also in 1924 the pilots Brito Pais and Sarmento Beires idealized the conducting of a trip to Macau as an aspiration for a future Portuguese around the World Flight attempt. On 7 April 1924, those pilots departed from Vila Nova de Milfontes in a Breguet XVI Bn2 airplane, beginning a trip to Macau. On 7 May an engine failure forced them to crash in India. On 30 May they managed to continue the Voyage in a De Havilland DH9 aircraft before being forced to end their attempt in 20 June in flying over Macau. A typhoon hindered their efforts to land and the airplane was crash landed in Chinese Territory about 800 meters from the Hong Kong Border. On 25 June 1924, they were shuttled back to Macau by boat. Brito Pais, Sarmento Beires and Manuel Gouveia returned to Portugal, via North America, visiting several Portugueses nuclei at China, Japan, United States and England. They went to Portugal on 9 September, after having flown a total of 16,760 kilometers in 117:41 h facing often extremely adverse atmospheric conditions, sandstorms and inaccurate navigation maps [8]. Figure 3 illustrates the navigators and the airplanes used along the First Aerial Journey from Portugal to Macau.

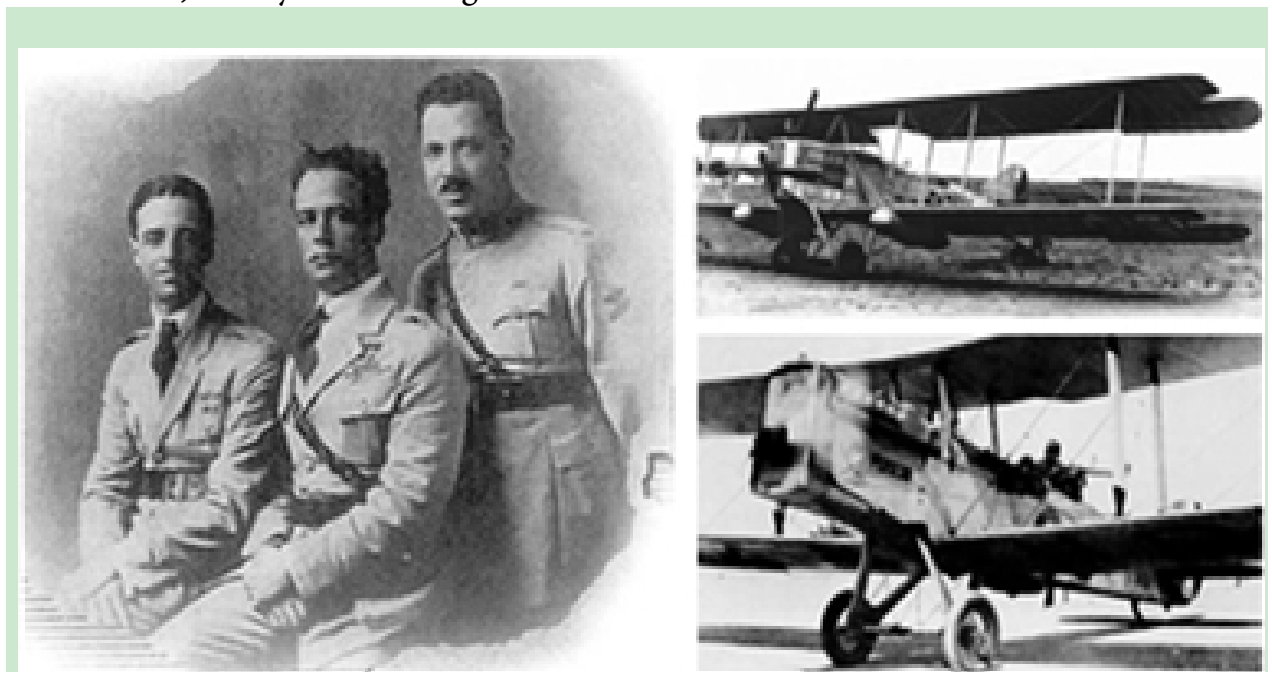

Figure 3. Portraits of Sarmento Beires, Brito Pais and Manuel Gouveia; picture of the Breguet XVI bn2 "Pátria” (above, right); and of the De Havilland Dh 9 "Pátria IP” (above, left) [1]. 


\subsection{First Aerial South Atlantic Night Crossing-1927}

On 16 February 1926, Sarmento Beires started writing a preliminary draft for a trip around the world that included the main requirements: an aircraft for the trip; the required crew; all stages and stopover locations; total monetary costs and the refueling stations that had to be organized around the World. On 19 February this document was delivered for appraisement at the Inspecção de Aeronáutica Militar na Direç̧ão da Arma de Aeronáutica (Military Aeronautical Board of Inspectors at the Directorate of Aeronautics Weapon). On 3 March the document was discussed by the Technical Committee of the Directorate of Aeronautics Weapon which transmitted a concurring opinion. On 10 March a copy of this document was send off to the War Ministry Cabinet Office. On 7 May a meeting was held on which was widely discussed once for all, the technical features of the airplane to choose. The frequent replacement of wheels by floats was not accepted due to the difficulty and the floats hardness was considered questionable. The final airplane option considered for use was a metal boat-hull fuselage seaplane. The technical discussion about the power plant was decided in favour of a Lorraine Dietrich twin-engine seaplane. After a new briefing round with manufactures representatives the chosen seaplane was a modified (by request) Dornier-Wal model, manufactured by the German company, Dornier Flugzeugwerke. By the Directorate of Aeronautical Weapon request, Sarmento Beires proceeded to several modifications as necessary and tried to complement the initial preliminary draft program. On 8 June the modified preliminary draft was again endorsed to the Technical Committee which transmitted again a favorable opinion, yet still reserving the right to propose amendments if necessary. Meantime the journey route was modified to follow the clockwise direction due the prevailing winds. This new route would have three main legs. The first leg involved the crossing of the Atlantic, Brazil, Argentina, to Chile in a distance of 12,000 km. The second leg involved the crossing of the Pacific via Tahiti, Australia, Timor, with a four days stop for engines replacement. The longest stage (3084 km) was from the Juan Fernandez Island to the Easter Island. The third leg involved the trip to Singapore, Ceylon (actual Sri Lanka), Goa, Karachi, Bushehr, Alexandretta (actual İskenderun), Bizerta and Lisbon. On 14 June the Military Aeronautical Board of Inspectors requested to the Ministry of War Cabinet the monetary funds to carry out the journey. The prior approval of the preliminary draft and all subsequent discussions and amendments had already led to several legal commitments insured with some manufacturers. Furthermore, France, Germany, Italy and England already had the journey completion knowledge. Finally on 23 July the Ministry of War issued an unofficial statement saying that the Portuguese Government had authorized the completion of the journey around the World. In 2 March 1927 and by following all the knowledge obtained by the First Cross of the South Atlantic, Sarmento Beires, Jorge Castilho, Duvalle Portugal and Manuel Gouveia started a new mission that became known as the First Aerial South Atlantic Night Crossing (Figure 4). During the night of 16 to 17 March 1927 a Portuguese crew flew $2595 \mathrm{~km}$ over the Atlantic Ocean from Guinea, Africa to Fernando de Noronha Island, Brazil [8]. The flight was made only by astronomical processes navigation resources that proved again to be absolutely feasible 


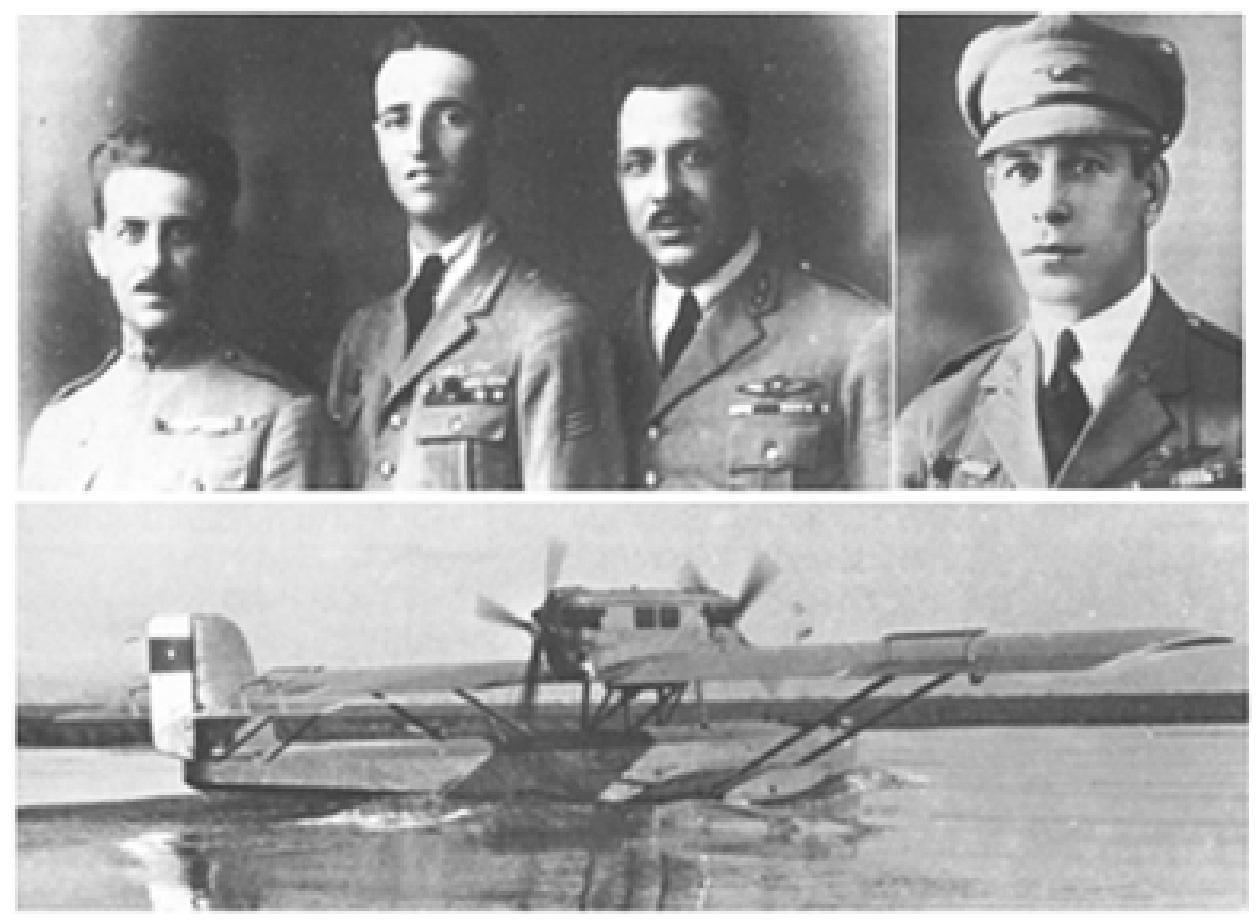

Figure 4. Portraits of (left to right) Jorge Castilho, Sarmento Beires, Manuel Gouveia and Duvalle Portugal; picture of the seaplane Dornier Do J Wal "Argos" [9].

and trustworthy, regardless day or night lighting conditions [4]-[7] [9].

\subsection{Aerial Navigation Results Obtained with the Precision Sextant}

The First Flight from Europe to the South Atlantic was performed by Coutinho and Cabral; this Journey was conceived as well for the first time with exclusive use of astronomic navigation when flying out of sight of land was described. The navigation methods and instruments were tested during short flights, and then applied with quite success to the flight between Lisbon (Portugal) and Recife (Brazil) in 1922. For the first time in the history of the aviation the crossing of the South Atlantic had been achieved and using an instrument that enabled an aero plane position to be determined by astronomic navigation when flying out of sight of land. Immediately after the Portuguese Air Journey that became known in the World as the First Aerial South Atlantic Night Crossing 1927, Jorge Castilho wrote in his report: “... Creio que foi a primeira vez que um aviáo passou uma noite inteira a voar sobre o mar e sem ter para se orientar outro recurso além dos processos astronómicos que se mostrou serem absolutamente praticáveis e dignos de confiança ..."; “[... I believe it was the first time that an airplane flew an entire night over the ocean having for its guidance resources only astronomical processes which proved to be absolutely feasible and trustworthy ...]".

\subsection{Early Portuguese Participations on International Aviation Congresses-1927 and 1932}

In the IV Congress of the International Air Navigation, Rome, 1927, Gago Coutinho 
and Jorge de Castilho advocated the Portuguese scientific methods of aerial navigation: the precision sextant and the path corrector used for the first time in the First Crossing of the South Atlantic. A Portuguese paper concerning these subjects and entitled "Portugal s Contribution to the Development of Air Navigation" was presented by J. Lobo D Avila Lima at the Air Navigation Section of this Congress [10]. On 1932 in the I International Congress of Transoceanic Aviators, Rome, highest honors were given at the Portuguese concerning the two Crossings of the South Atlantic in 1922 and 1927 and their methods of navigation; they were used by many of the major airlines of the world throughout the 1930's [1].

\subsection{Sociedade Portuguesa D’Estudos E Linhas Aéreas, Limitada-1929}

The Portuguese Government was interested in the possibility of using the Azores, Madeira and the Cape Verde Islands as stages on an air route to South America, and in January, 1929, a national air council was established for the consideration of general air policy. A few months later military and naval aviation commissions were set up. Shortly after its formation a concrete proposal was submitted to the air council by the Serviços Aéreos Portugueses, who asked for a concession of 18 years' duration to fly regular mail services between Portugal and the Azores. The proposal was rejected. Later two French companies, the Société des Moteurs Gnome et Rhone and the Compagnie Générale Aéro-Postale came to an agreement and formed a combination known as the Sociedade Portuguesa de Estudos e Linhas Aéreas, Limitada, or S.P.E.L.A., as it is styled, with an office in Lisbon. It was announced in the local press that the purpose of the company was to obtain from the Portuguese Government a concession to operate a commercial airway from Portugal via Madeira, down the west coast of Africa to the Portuguese colonies. The proposals submitted by S.P.E.L.A. were eventually accepted in December, 1929. The concession was to run for 35 years, being thereafter renewable for periods of five years at a time. The company was to be Portuguese with headquarters on Lisbon and the majority of the personnel must be Portuguese citizens, a regular air service would be maintained from Portugal via the Azores, to Angola, and across to Mozambique. The question of aerodromes were also been occupying attention of the Portuguese Government; those already in existence were few in number and poor in quality; the best was at Alverca, a good level space measuring 800 metres by 500 metres, 14 miles north-east of Lisbon on the right bank of the Tagus (river). In the north of Portugal a single hangar was built by the Aveiro lagoon, 25 miles south of Oporto. During the summer of 1929 arrangements were made for two Portuguese flying instructors to proceed to England for the purpose of special training [11].

\subsection{Airplanes and Engines Manufactured at Portugal}

The Alverca workshops were very well equipped, and were adequate for the volume of work they were called upon to handle. A careful system of checking and testing, under the supervision of Engineer-Officers of the Aeronáutica Militar, together with an elaborate costing system, was employed. Alverca also possessed an efficient workshop for 
wooden wing construction, and another for the manufacture of wooden airscrews. Airscrews are supplied to the Military and the Naval Air Force. As regards aircrafts, several types were constructed under license that time in Alverca: the Potez XXV, the Vickers Valparaiso (Type 93 Valparaiso I, Type 92 Valparaiso II and Type 168 Valparaiso III) and the Pou-du Ciel (Flying Flea). The majority of the engines in the airplanes of the Military Air Force are Bristol "Jupiter' $s$ " and all of this make have either been totally constructed at Alverca, or else parts constructed from parts imported in the rough and machined up and assembled in the Alverca Workshops [12]. Figure 5 illustrates the Alverca facilities and a Potez XXV airplane entirely built at Portugal.

\subsection{Aero-Portuguesa: Portuguese Air Mails-1934/1953}

A contract between the Posts and Telegraphs Department and the Aero-Portuguesa Limitada, for the carriage of air mail matter between Portugal and Morocco-and thence to and from South America-was signed in Lisbon on 8 November 1934. The Aero Portuguesa Ltda. undertakes to provide one service between Lisbon and Tangiers weekly, on Saturdays to Tangiers and on Sundays back to Lisbon.

The service was to run in such a manner that connections between the Portuguese aircraft and the southbound Air France machines shall be ensured. The company made a deposit of Esc. 20,000,000. The contract was to last one year and at the expiration it could be renewed if the Government so wishes. By giving thirty days' notice either party may bring an end to the contract. The Posts and Telegraphs Department guarantees to utilize the Company's facilities for all mail matter destined by senders to travel by air. It reserved the right to use in case of necessity or convenience any other aerial services which could, in the future, be established in Portugal. The contract could be cancelled, for instance, should four consecutive trips fail to be run [13]. The official inauguration of the Aero-Portuguesa service, linking Portugal with the Air France line to South America, took place at Alverca International Aerodrome on 20 October 1934. The first airplane used on this service was a Fokker F.VIIb-3 m (powered with three GnomeRhone "Titan" engines). For Tangier there were but three passengers as well as $13 \mathrm{~kg}$ of mail. A large gathering of representatives of the Portuguese Government, of the various Ministries, the Director of Military Aeronautics, propaganda and commercial associa-
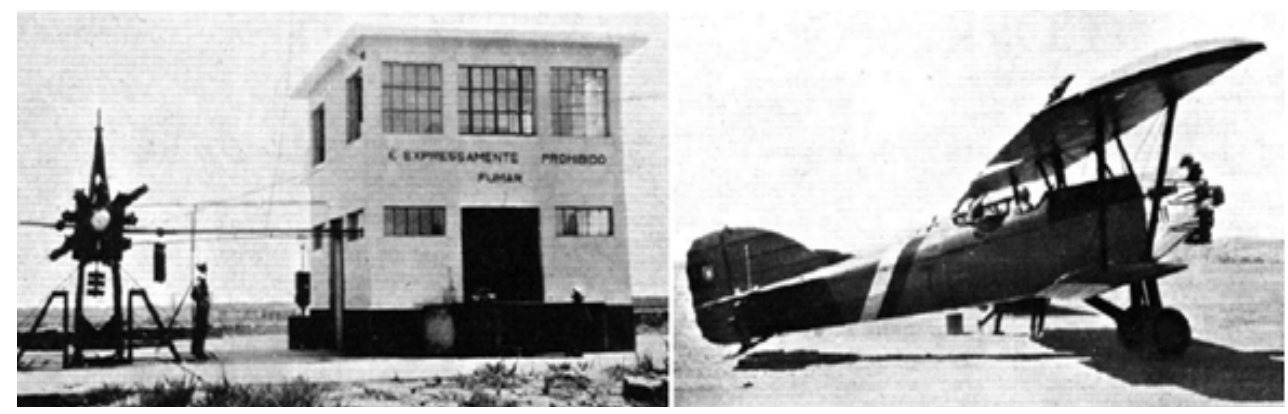

Figure 5. View of the torque-reaction test bench of the Bristol "Jupiter" engines built in Portugal under license (at Alverca); a Potez XXV airplane with a "Jupiter" engine-both entirely constructed in the Alverca workshops [12]. 
tions, native and foreign Press, and a crowd of sightseers, were also present [14]. On January 1937 Air France South American service was timed to connect with AeroPortuguesa's weekly Lisbon-Tangier service, ensuring a three-day delivery mail between Lisbon and Brazil. The link between Portugal and Morocco reached a high importance along the $2^{\text {nd }}$ World War, since the Aero-Portuguesa become the only aviation company from a neutral Country, allowed to operate inside belligerent territory. The Aerostructed in the Alverca workshops [12].

Portuguesa company ended its operations in 1953 with the integration of its services on TAP (Transportes Aéreos Portugueses).

\subsection{First Portuguese Airplane: A Flying-Boat Glider-1934}

On February $1^{\text {st }} 1934$ Joe Walter presented a gliding section creation proposal where it was included the flight report study and the flight graph of the flying-boat glider of Eng. Artur Varela Cid, the first designed and constructed in Portugal (construction finished in 29 September 1932) with its first maiden flight on January $4^{\text {th }} 1934$. This flying-boat glider was named "Portugal" and presently can be found at the Air Museum of OGMA, Oficinas Gerais de Material Aeronáutico (The General Aeronautical Material Workshops) at Alverca, Portugal. Few months later still in 1934, in a lecture at Society of Geography at Lisbon, Professor Varela Cid advocates the creation of Non-Pow- ered Flight Schools, where gliders construction would be included and where rigorous theoretical training would be given.

\subsection{Primeira Exposição Internacional De Aeronáutica-1935 (First International Aeronautical Exhibition)}

June 2 to 15, 1935, Major José Pedro Pinheiro Corrêa held the $1^{2}$ Exposição Internacional de Aeronáutica, (First International Aeronautical Exhibition Figure 6), a unique event in Portuguese field which resulted in a great and successful large projection beyond borders. In addition to national section, Great Britain, Czechoslovakia, France, Italy and Germany offered their collaboration. On this Exposition were the Bristol " $\mathrm{Ju}$ piter" engines and the Gnôme \& Rhône engines both made in Alverca, Portugal. These engines were carried out under the direction of Monsieur Charles le Gac, a French engineer of the Société des Moteurs Gnôme \& Rhône, holders of the Bristol license. The testing of these engines after constructions is carried out under the direction of Monsieur Réné Lepray, also an engineer of the Société des Moteurs Gnôme \& Rhône. M. Lepray has put up a torque-reaction test apparatus having incorporated many ingenious devices of his own adaptation (if not invented) not found in normal test-benches. Suspended from the roof is the Portuguese flying-boat glider of Artur Varela [15].

\subsection{The Birth of the Gliding at Portugal-1937/1938}

Meanwhile in 1937 the Aero Clube de Portugal created the Revista do Ar (Journal of Air). In $\mathrm{n}^{\mathrm{er}} 7$ of this magazine, Humberto Delgado publishes the article " $A$ Aviação na Mocidade Portuguêsa" (The Portuguese Youth Aviation), thus releasing the gliding birth in Portugal. The first glider Flight School was named Escola Bartolomeu de 


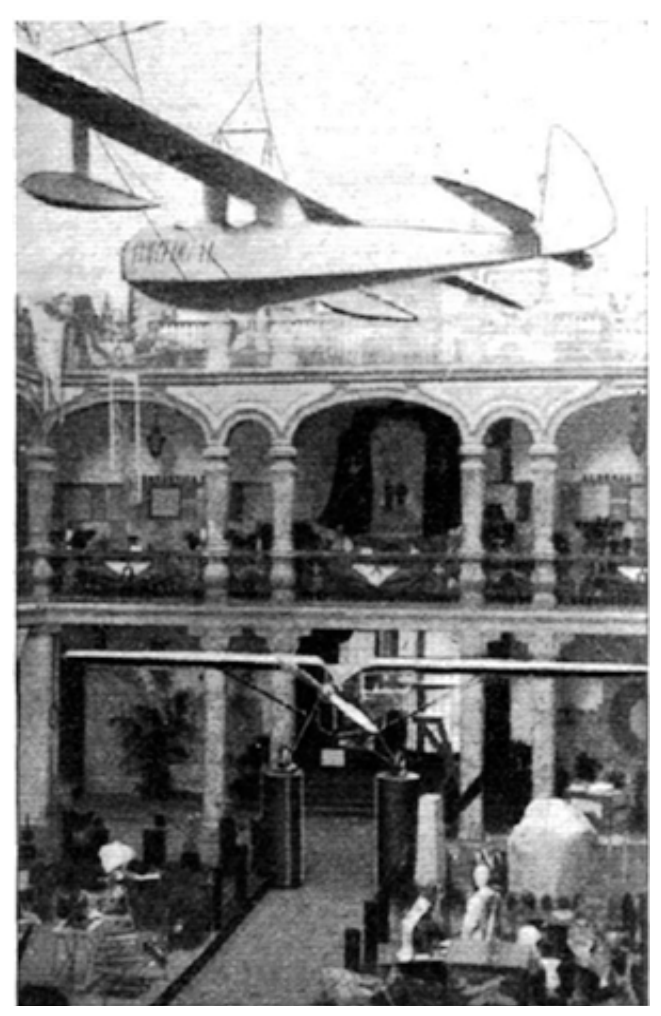

Figure 6. View of the First International Aeronautical Exhibition-over the aisle was the D.H. "Leopard Moth" in which Lt. Humberto da Cruz and Sgt. Mech. Lobato flew from Lisbon to Timor. Suspended from the roof is the Portuguese "Varela Cid' flying-boat glider [15].

Gusmão and in September 1937 with the Germany's support, leader of non-powered flight aviation, begins the course of gliding with 14 students, under instruction of Pilot Engineer Karl Bauer and his assistant Hanz Scholz, with the use of a two-seater Kranich I glider's model purchased for the Portuguese State. The first Portuguese glider pilots obtained their licenses in Germany in 1938. Captain Quintino da Costa was then nominated to replace the function of Karl Bauer as flight instructor [2].

\subsection{The Birth of TAP-Transportes Aéreos Portugueses-1945}

Officially in 1939, Portugal declared its war neutrality which remained until the end of hostilities. The 1940s slowed down the entire aircraft frenzy lived before the War in Portugal. The TAP-Transportes Aéreos Portugueses (Portuguese Air Transportations) were founded on March 14, 1945 and in the following year the first aircraft were purchased, a DC-3 Dakota. On September 19, 1946 was inaugurated the first commercial regular flight from Lisbon to Madrid. On December 31 of that year, it was inaugurated an Imperial regular flight from Lisbon to Luanda and from Luanda to Lorenzo Marques with twelve scales. The first domestic regular flight from Lisbon to Oporto started in 1947 [2]. 


\subsection{Second Portuguese Airplane: A Hydroplane-1947/1948}

Around 1947/48 Artur Varela Cid Professor of Aerodynamics designed and constructed another hydroplane named "São Miguel" with the help of Instituto Superior Técnico. In 1948, during the $2^{\circ}$ Congresso Nacional de Engenharia, Porto $\left(2^{\text {nd }}\right.$ National Engineering Congress, Oporto) Artur Varela Cid present three papers related to National Aeronautics: A Construção Aeronáutica em Portugal (Aeronautics Construction at Portugal); O hidroplanador Portugal (The flying-boat glider Portugal) and O Futuro Projecto do Centro para Estudos Aeronáuticos a construir no Instituto Superior Técni$c o$ (The Future Project of Aeronautics Studies Center to be built on IST) [2].

\subsection{Intergovernmental Military Alliance-OTAN/NATO-1949}

After World War II, in 4 April 1949, Portugal became member of the North Atlantic Treaty Organization (NATO/OTAN) Intergovernmental Military Alliance. The Portuguese Minister of Foreign Affairs, José Caeiro da Matta, signed the Treaty, which entered into force on 24 August 1949, after the deposit of the ratifications of all signatory States. The Portuguese Government starts to made legislation in a way to adapt the Country to the NATO Treaty. By the Decreto-Lei n 37909 do Diário do Governo, de 1 de Agosto de 1950 (Decree-Law n ${ }^{\text {er }} 37909$ of Government Diary, of 1 August 1950) it was created the Ministro da Defesa cargo and the Chefe do Estado-Maior das Forças Armadas (CEMGFA) cargo. These two cargos were created as a way to implement some transformations in national Aeronautics scope. That Decree-Law determines also a Ministry alteration: the Ministério da Guerra (War Ministry) changes for Ministério do Exército (Army Ministry). It was also created the Subsecretariado de Estado da Aeronáutica (Office of Subsecretariat of State for Aeronautics), in order to supervise and to equip all Portuguese military aviation. The Subsecretariado de Estado da Aeronáutica has direct dependency on the Ministro da Defesa. On June 27, 1952 it was enacted the Lei 2055 establishing the FAP-Força Aérea Portuguêsa (Portuguese Air Force-Coat of Arms of FAP is illustrated at Figure 7) as an independent branch of the Forças Armadas. On June 28, 1952, the office of Undersecretary of State of Aeronautics was created. From 1 July 1952 onwards, the Subsecretariado de Estado da Aeronáutica

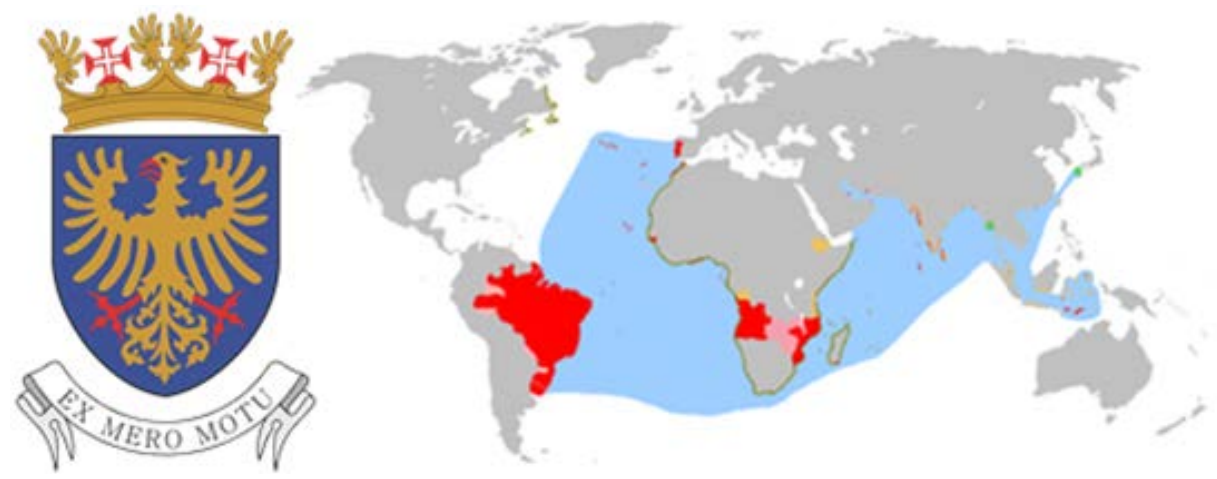

Figure 7. (Left): Coat of arms of the Força Aérea Portuguesa with the Latin sayings EX MERO MOTU, meaning "out of mere impulse", and; (right) map of the Portuguese Empire territories [3]. 
(Undersecretariat of State of Aeronautics) supervises directly all of the following services: from the Ministério do Exército (Ministry of Defense); the Comando-Geral da Aeronáutica Militar (General Command of Military Aeronautics); the Depósito Geral de Material Aeronáutico (General Deposit of Aeronautical Material); the Oficinas Gerais de Material Aeronáutico (Workshops General Aeronautical Material); the Bases Aéreas (Air Force Bases) 1 - 3 and 4, the Grupo independente de Aviação de Caça (independent Group of Fighter Aircrafts), and all aeronautical facilities currently under the Army Ministry. As well the Under secretariat of State of Aeronautics supervises directly all of the following services: from the Ministério da Marinha (Navy Ministry); the Comando Superior das Forças Aéreas da Armada (High Command of the Navy Air Forces); the Direcção da Aeronáutica Naval (Naval Air Force Direction); the Centro de Aviação Naval de Lisboa (Naval Aviation Center of Lisbon); the Escola de Aviação Naval Almirante Gago Coutinho (Naval Aviation School Admiral Gago Coutinho); the Grupo independente de Aviação de Caça (independent Group of Fighter Aircrafts), and all aeronautical facilities currently under the Navy Ministry. This meant the birth of Força Aérea Portuguêsa. In 1953, the Escala Geral do Quadro dos Engenheiros das Forças Aéreas: Aeroterrestre, Aeronaval e Força Aérea (General Board of the Air Forces Engineers: Airborne, Naval and Air Force) shows some officers who were taking technical training abroad. From the Naval Air Force, five Naval Machinery Engineers went to England to obtain their expertise in Aeronautics and engines. From the Airborne Air Force, nine Pilots Aviators went abroad to obtain their expertise in Aeronautics and engines. In the Air Force, thirteen Electrical Engineers in 1953 went to United States to obtain their expertise in Radar. (Ordem á Aeronáutica, 2a Série/n ${ }^{\circ} 6$ de 20 de Novembro de 1953, Página 103). In the 1950s the colonial territories of Portugal and the remnants of the Portuguese Empire comprised a wide area throughout the world, from Brazil to East Timor (Figure 7). Through the Diário da República, Série I, $N^{\circ} 282$, Decreto-Lei $n^{\circ} 40949$ de 28 Dezembro de 1956, the Air Force was reorganized and the term "Air Force" (singular) began to be official, alternatively to "Military Aviation" that will fall into disuse in the future. This Decreto-Lei $n^{\circ} 40949$ on its Capítulo IV, Art 50", stipulates the National territory (metropolitan and overseas) three major aerial divisions which began to exert its own control of the air units stationed inside each area: $1^{\text {st }}$ Aerial Region with headquarter at Lisbon, included Portugal, Azores, Madeira and Cape Verde; $2^{\text {nd }}$ Aerial Region with headquarter at Luanda, included Angola; Guinea and Sao Tome and Prince and $3^{\text {rd }}$ Aerial Region with headquarter at Lorenzo Marques, included Mozambique, Portuguese India, Macau and East Timor. Due to the specialized Aeronautics personnel needs, in 1954 Portugal had more than more 200 students attending their courses and internships abroad.

In 1955 there were about 100. In 1956 Portugal began to recruit staff in order to graduate abroad in the Aeronautics Engineering course. The Air Force (due to the Quadros Superiores formation needs) and OGMA (now responsible for the Overall Aircraft Services at all types of existing aircraft in the Portuguese Armed Forces and also as a manufacturer of instruction aircrafts-Decreto-Lei $n^{\circ} 40391$ de 22 de Novembro de 
1955) had a growing capital needs of staff with expertise in this area. In 1958 Professor Artur Varela Cid presented to IST the publication entitled Futuras Instalações do Centro para Estudos Aeronáuticos e seus laboratórios a Construir no Instituto Superior Técnico (A comprehensive view of the future of aeronautics teaching and a proposed research center of aeronautical studies with specific laboratories) [2].

\section{Aerospace Introduction}

\subsection{Foundation of the Observatório Astronómico De Lisboa}

The foundation of the Observatório Astronómico de Lisboa (Astronomical Observatory of Lisbon) was sponsored by the Portuguese King D. Pedro $V$ and supported by Friedrich Georg Wilhelm Struve, Director of the Pulkovo Observatory of Russian Academy of Sciences. This Observatory owes its own birth due to a dispute between the Director of the Observatory of Paris, Hervé Fayel and Friedrich Georg Wilhelm Struve, on the determination of the parallax of the Star Argelander or Star Groombridge 1830 (located in Ursa Major). In February of 1850, Faye made a proposal for the settlement of the dispute. Precise observations of that Circumpolar Star should be conducted, and the place to do it was Lisbon, since this was the only site in Europe where the star could be observed in the correct circumstances. He went on to propose that he would conduct the observation campaign in person, using the zenithal refracting telescope that he had built for the purpose. The planning of the observations was worked out between himself and Struve. Lisbon offered the geographic and climatic especially favorable conditions to study the stellar and nebulae parallaxes, not only by the frequency of clear sky periods as also the number of stars considered more favorable for measuring parallax (1830 Groombridge, 61 Cygni, Alpha Lyrae) passed near the zenith, thus reducing errors due to atmospheric refraction. This favorable natural conditions and the addition of several scientific navigation instruments such the octant, the sextant, the quadrant, the astrolabe, the balestilha or the astronomical tables, would have probably favored the Portuguese Descobrimentos success. The Observatório Astronómico de Lisboa began to be constructed on 11 March 1861 and was completed in 1867, year of the very first observations. It was subsequently created by the Carta de Lei (Law Chart) of 6 May 1878 [16].

\subsection{Foundation of the Centro De Estudos De Astronáutica-1958}

The Ministry of National Education created the Centre for Astronautical Studies, placed under the wing of the Portuguese Youth (Mocidade Portuguesa). Eurico da Fonseca was appointed director, and given, as main objective, the promotion of the "conquest of space". This organization produced weekly radio shows and a regular bulletin named "Astronáutica" with information and discussions on subjects related to space exploration and astrophysics [16].

\subsection{Planetário De Lisboa-Overture: 1965}

Has a result of the lobbying by the Portuguese Astronomical Society (founded in 1917) and the realization of the ancient dream of a Navy officer and astronomer Commander 
Eugénio Conceição Silva (who pushed hard for its construction), in 1965, the Lisbon Planetarium opened to the public with the name of Calouste Gulbenkian (this Foundation financed the acquisition of the projector) [16].

\subsection{Centro Espacial De Mulemba, Angola-1965}

Also in Angola, 1965, the radio astronomer amateur Carlos Bettencourt de Faria [17], (Figure 8) pursued his lifelong passion and built a Space Centre at Mulemba (Observatório de Mulemba) using as materials little more than junk, and putting to use his admirable resourcefulness. Thanks to the privileged location of this private tracking facility, the images collected by the satellites that came into view of the station in three or four sequential passages allowed for the construction of global mosaics of the African continent. NASA, through the Goddard Space Flight Center, supplied the Mulemba Space Centre with regular bulletins, with the schedules of the polar orbits of a number of satellites which collected images of the surface of the Earth and sent them back by VHF radio [16].

\subsection{Astronauts Visiting Portugal}

During the 1960s and 1970s, Portugal was visited on separate occasions by several astronauts. The first visitor was John Glenn, on the 19th October, 1965 (Mercury-Atlas 6 and STS-95). Upon his arrival, the first American to orbit the Earth pronounced a speech in which he compared the Portuguese and their discoveries with the Americans and their spatial adventures. According to his own words, "Portugal began the Descobrimentos and the Americans keep going it". The objectives of his visit were to pay his respects in the name of the new discoverers, and to spread the word, by sharing his experiences with students, universities and companies. In February of 1969, by the Gago Coutinho's centenary birth, Frank Borman was in Portugal. The Commander of the Apollo-8, the first that orbited the Moon from $21^{\text {st }}$ to $27^{\text {th }}$ December 1968, gave a lecture at the Portuguese National Laboratory of Civil Engineering. He explained that the principle of Gago Coutinho was present in the Apollo-8 flight. In fact, "a sextant used in aeronautics for the first time in the world by the Portuguese genius" was mounted to
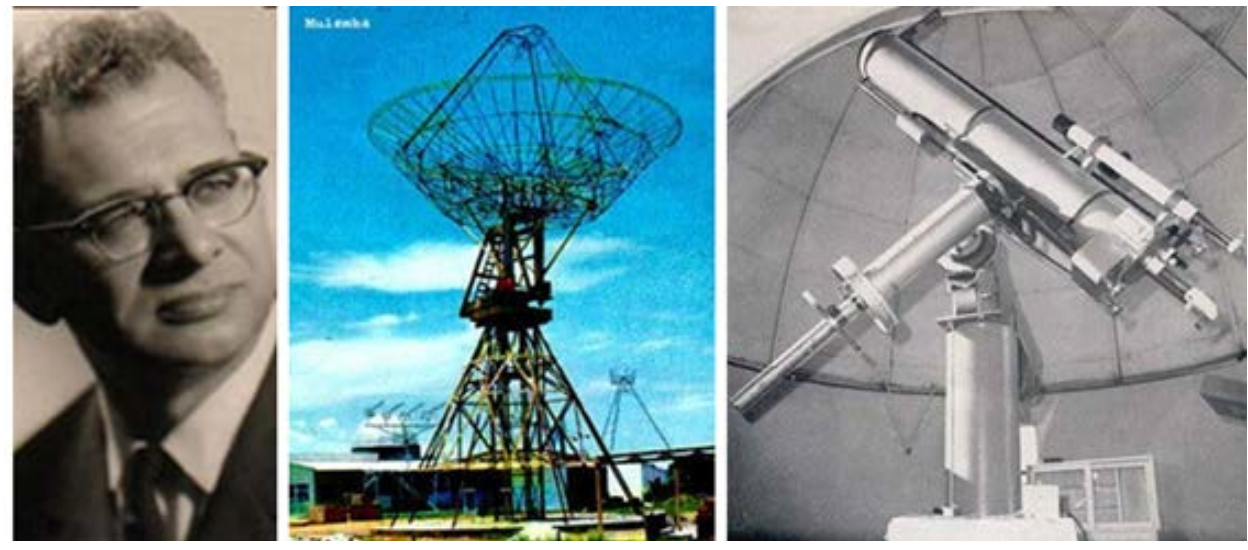

Figure 8. Carlos Bettencourt de Faria and photos of the Centro Espacial de Mulemba, Angola [17]. 
a telescope. He detailed that these instruments was connected to a computer, which indicated that the final accuracy of the error was 0.001 degree $^{1}$. In 1971, James Lovell and Stuart Roosa were at Portugal; James Lovell, most famous as the commander of the Apollo 13 mission, which suffered a critical failure en route to the Moon but was brought back safely to Earth by the efforts of the crew and mission control. Lovell was also the command module pilot of the Apollo 8, the first Apollo mission to enter lunar orbit; Stuart Roosa, most famous as the command module Pilot for the Apollo 14 mission (lasted from January 31 to February 9, 1971). In 1975, James Lovell and Valentina Tereshkova were at Portugal; Valentina Tereshkova, most famous as the first woman to have flown in space, having been selected to pilot Vostok 6 (16 June 1963) [1] [3] [16].

\subsection{Comissão Permanente De Estudos Do Espaço Exterior-1970}

In 1970, by the Portaria $\mathrm{n}^{\circ} 29$ de 14 de Janeiro de 1970 the Junta Nacional de Investigação Científica e Tecnológica (National Board for Scientific \& Technological Research) created an entity named Comissão Permanente de Estudos do Espaço Exterior (Permanent Commission for the Study of Outer Space).

The tasks attributed to this Commission meant that it should keep up to date on any plans and developments of national entities, public or private, that were involved in any type of research referring to extra-atmospheric space, and in any applications thereof. It also had the responsibility of encouraging the formation and specialization of the scientific personnel which was and would be needed to undertake the future plans and activities of the country in the area. After Portugal's participation in the United Nations Conference on the Peaceful Utilization of Outer Space the Comissão Permanente de Estudos do Espaço Exterior, organized its first Seminar on Remote Sensing in Lisbon, 1976. The second Seminar edition was in Oporto, 1978 and the third back to Lisbon in 1980. By the Diário da República, série I, nº 64, Portaria n 292 de 18 de Março de 1983, the Comissão Permanente de Estudos do Espaço Exterior began to include representatives from the Direcção-Geral dos Negócios Políticos, Direcção-Geral dos Negócios Económicos, Estado-Maior da Força Aérea, Base Aérea n 1, Estado-Maior da Armada, Instituto Hidrográfico, Estado-Maior do Exército, Serviço Cartográfico, Instituto de Investigação Científica Tropical-JICU, Instituto Nacional de Investigação Científica, Observatório Astronómico de Lisboa, Direcção-Geral da Aviação Civil, Instituto Nacional de Meteorologia e Geofísica, Direcção-Geral dos Recursos e Aproveitamentos Hidráulicos, Direcção-Geral das Florestas, Direcção-Geral do Ordenamento, DirecçãoGeral da Qualidade do Ambiente, Laboratório Nacional de Engenharia Civil, Instituto

${ }^{1}$ In 1971, Francis Millet Rogers, from Harvard University write a book entitled "The Portuguese Contribution to Air Navigation Precision Astrolabe; Portuguese Navigator and Transoceanic Aviation" published in Lisbon by the Academia Internacional da Cultura Portuguesa, and distributed in the U. S. A. by W. S. Sullwold, Tauton, Mass. In 1973, Colter, H. C. publishes his work entitled "An Early Portuguese Contribution to Air Navigation”, The Journal of Navigation, Volume 26, Issue 03, July 1973, pp. 382-385. In this paper, the author made references to Coutinho's process of navigation "which made the calculations on the eve of the flight so that the line position was drawn in the flight chart nearly 5 minutes after the end of observation, and while crossing the Atlantic South, close to equator line, this time was reduced to 3 minutes" was an unprecedented simplification studied by Coutinho. 
Geográfico e Cadastral, Instituto Nacional de Investigação das Pescas, Instituto Nacional de Investigação Agrária e Extensão Rural, Correios e Telecom-unicações de Portugal, Universities (with no more than 3 personalities with recognized merit in the field, where must be included one personality of Astronomy and one personality of Aeronautics) and also no more than 6 personalities with recognized merit in a area of activities connected to outer space pacific utilization [16].

\subsection{International Astronautic Congress, Lisbon-1975}

Lisbon was chosen as the venue to the XXVI International Astronautic Congress, thanks largely to the efforts of Prof. Artur Varela Cid, of the IST. The event took place from 21 to 27, September 1975 at the Calouste Gulbenkian Foundation. Many important names in the engineering and scientific fields of Astronautics were present such as the American Krafft Ehricke, who had been involved in the analysis and planning of manned Mars missions; the American Milton Rosen, who had been in charge of early attempts by the United States Navy to launch artificial satellites; the Czech-American Frank Malina, who had chosen to live in France after he left a field that in his view became too closely linked to weapons development; the French Jean-Jacques Barré, one of the pioneers of rocket propulsion in his country since the 1930s. Soviet Union sent the cosmonauts Vitali Sevastyanov and Pyotr Klimuk, who had recently spent two months in space on board the orbital station Salyut 4 and Leonid Sadov, at the time a prominent figure in the soviet space program, and who led the delegation of the Academy of Sciences of the USSR. The chief of the Military House of the Portuguese President was the designated officer to greet the participants. In his opening discourse, he thanked the homage paid by the ICAS Congress, in July 1974, related to the celebrations of the 50 years of the trans-Atlantic flight between Lisbon and Rio de Janeiro, accomplished by Gago Coutinho and Sacadura Cabral [16].

\subsection{POSAT-I: First Portuguese Satellite: A Micro-Satellite-1993}

On April 6, 1992, both Universidade da Beira Interior and the Instituto Superior Técnico, among other stakeholders such as LNETI-Laboratório Nacional de Engenharia e Tecnologia Industrial (National Laboratory of Industrial Engineering and Technology), the CPRM-Companhia Portuguesa Radio Marconi, Alcatel, Corinde-Comissão Instaladora de Reestruturação da Indústria da Defesa (Commission of Instalment and Restructuring of the Defence Industry), Efacec-Empresa Fabril de Máquinas Eléctricas (Manufacturing Company of Electric Machines) and CEDINTEC-Centro para o Desenvolvimento e Inovação Tecnológicos (Center for Development and Technological Innovation), have signed a Consortium Agreement for the first Portuguese satellite construction, PoSAT-1 (Figure 9). The satellite belongs to the micro-satellites class, is an aluminum parallelepiped box with $35 \mathrm{~cm}$ length for $35 \mathrm{~cm}$ depth with $58 \mathrm{~cm}$ height dimensions and weighs about $50 \mathrm{~kg}$. It was launched into space on the flight $\mathrm{n}^{\text {er }} 59$ of the Ariane 4 rocket (Kourou Space Center, French Guiana). After $807 \mathrm{~km}$ PoSAT-1 went into space orbit on September $26^{\text {th }} 1993$, at 2:45 a.m. Lisbon time [3] [16]. 


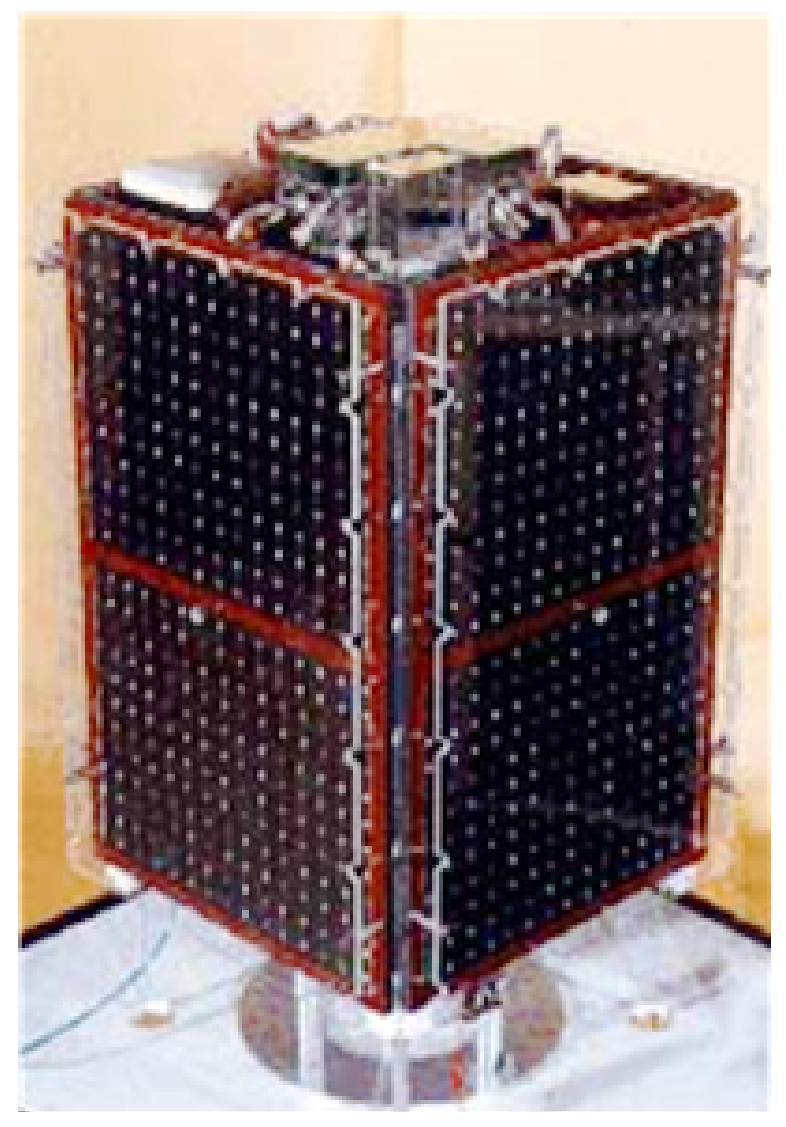

Figure 9. PoSat-1 photo; a "mock-up" of this satellite can be found at Aerospace Sciences Department, UBI at Covilhã, Portugal.

\subsection{Portugal: A Member-State of European Space Agency-2000}

In 2000, Portugal became a Member-State of ESA, The European Space Agency. ESAwas established in 1975 as an intergovernmental organization space exploration with 19 Member-States (January, 20 2011). In the last ten years, this membership has contributed decisively to the creation, development and consolidation of a new activity cluster. According to the ESA, Portugal participates in all major ESA programs, including the Telecommunications and Integrated Applications, and activities related to Galileo Navigation, Earth Observation and Science and Robotic Exploration, with a 302 global number of contracts assigned to Portuguese companies and academia from 2000 to 2009 [18].

\section{Aeronautics/Aerospace Engineering Degrees at Portugal}

\subsection{Foreign Aeronautics and Astronautics Specializations}

In 1963, the specialization stage of Aeronautics Engineering courses of the Portuguese Air Force was made in foreign Universities. And due to the limited admission number in these universities, Portugal resorted to several Countries in a way to meet its own Portuguese Air Force staff needs. However, it was observed a great heterogeneity in the 
technical training of Aeronautics Engineers, depending on the Country were they had obtained their Graduation. And it was also found that foreign Aeronautics Engineering courses were organized under particular conditions on dependence on the needs of their Countries, which were not always those best suited to the Portuguese Air Force. On the other hand, this Graduation system requires to Portugal a substantial monetary expenditure since it meant a permanence of students abroad for at least three years. The lack, scarcity, and sometimes the inadaptability of this system to Portugal's needs were factors that advise a national Aeronautics Engineering Degree creation in parallel with the other Engineering courses in Portugal. However, the structure of this course would be slow due to legal provisions applicable to already existing courses of equal nature, which did not fit with the Portuguese Air Force urgency requirements. It was then considered advantageous to create as quickly as possible an Aeronautics Engineering course for Portuguese Air Force military personnel that could eventually later be integrated with a civilian characteristics course at an already created University: Instituto Superior Técnico (Diário da República, Série I, No 197, Portaria n 20756 de 22 de Agosto de 1964, Págs. 1037 - 1038-Figure 10).

$5^{\circ}$ As matérias professadas nos três últimos anos do curso são as seguintes:

\section{$4^{\circ}$ Ano Académico}

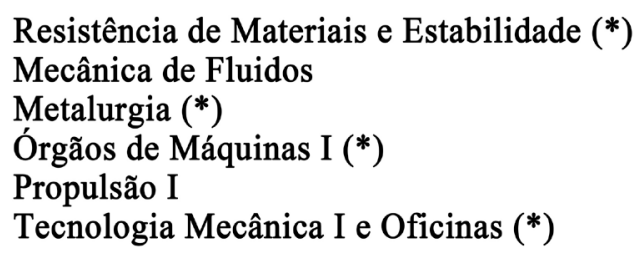

$6^{\circ}$ Ano Académico

Mecânica de Voo e Estabilidade

Máquinas Alternativas II (*)

Aeroelasticidade (S.)

Estruturas de Avião

Administração e Organização (*)

Automação

Laboratório de Aeronáutica

Figure 10. Subjects of the last three years of the first Aeronautics Engineering Military Degree at Portugal, 1963 (Portaria n 20756 excerpt). 


\subsection{IST: Aeronautics Engineering Course at Força Aérea Portuguesa}

Instituto Superior Técnico initiated the operation of the last three years of an Aeronautics Engineering course as a preparation means of Portuguese Air Force Aeronautics Engineers. The military students enabled with the Mechanical Engineering or equivalent preparatory years, were admitted to the frequency of the first year of this course. The Direcção do Serviço de Recrutamento e Instrução da Força Aérea (Directorate of Recruitment and Education of the Air Force) had the collaboration of the Instituto Superior Técnico, especially by the provision of premises to carry out theoretical and practical classes and by the faculty intervention that conducted some disciplines of the course. The optional disciplines of Aeronautics Engineering $\left(^{*}\right)$ were kept the existing ones at the $5^{\text {th }}$ and $6^{\text {th }}$ years of Mechanical Engineering course of Instituto Superior Técnico. In the academic year 1963/1964 the Portuguese Air Force had its first students attending a Aeronautics Engineering course which was proposed by Secretary of State for Aeronautics and worked in the Instituto Superior Técnico under the Junta Nacional da Educação decision (National Education Board) of 14 October 1963 and was also approved by the Minister of National Education dispatch of 2 November 1963. In 1961 the Undersecretariat of State for Aeronautics was replaced in 1961 by Secretary of State for Aeronautics. The Undersecretary of State for Aeronautics now had the status of Secretary of State for Aeronautics. During this course the Secretary of State for Aeronautics (Antonio Francisco das Chagas, 1962-1967; Fernando Alberto de Oliveira, 1967-1968 and José Pereira do Nascimento, 1968-1974) in agreement with the Minister of Education could made changes deemed necessary. This course was functioning till 1974. The civil counterpart took more 16 years to start. In the early 1990 s, three Aeronautics/Aerospace Engineering courses were created in Portugal: the first was created at the Universidade da Beira Interior-UBI (University of Beira Interior) in 1991. The second was created by the Academia da Força Aérea-AFA (Air Force Academy) also in 1991 and the Instituto Superior Técnico-IST (Lisbon Technical University) created the third in 1992 [2].

\subsection{UBI: Aeronautics Engineering Course at University of Beira Interior}

First steps leading to Universidade da Beira Interior were taken in the 1970s with the foundation of the Instituto Pólitecnico da Covilhã. Years later with the Decree-Law n ${ }^{\text {er }}$ 402 of $11^{\text {th }}$ September 1979 this institution was renamed Instituto Universitário da Beira Interior, with its conversion into Universidade da Beira Interior stated with the Decree-Law $n^{\text {er }} 76-\mathrm{B}$ of $30^{\text {th }}$ April 1986 publication. Professor Cândido Manuel Passos Morgado, AGARD National Delegate [19] from 1974 to 1976, AGARD Fluid Dynamics Panel member from 1963 to 1971, Major General Aeronautical Engineer of the Portuguese Air Force, graduated in Mathematical Sciences and PhD in Physics, was the first Rector of this University and stayed in office from $21^{\text {st }}$ August 1980 to $19^{\text {th }}$ January 1996. In 1991, as an initiative the Rector Professor Passos Morgado, UBI started teaching a 5 years Aeronautics Engineering Degree, which became the first Portuguese permanent and official civil Degree on Aeronautics. By Alvará de 6 de Fevereiro de 2010 
the President of the Portuguese Republic awarded Professor Passos Morgado with the Grã-Cruz da Ordem da Instrução Pública (Grand Cross of the Public Instruction Order) regarding his several cargos held during his academic career and also for supporting the Universidade da Beira Interior installation. The award was published at Diário

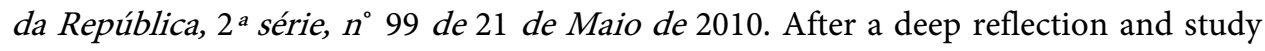
work conducted by a committee appointed for that purpose by the Conselho Cientifico (Scientific Council of the University of Beira Interior), at a meeting of this Council, on January 10, 1991, it was approved a proposal for a Aeronautics Engineering Degree creation, further evaluated and approved at Senado da Universidade (Senate) meeting on January 11, 1991. And in compliance with the Art $7^{\circ}$ do Decreto-Lei $n^{\circ} 21 / 89$ de 11 de Maio de 1989, (Article $7^{\text {th }}$ of Decree-Law ${ }^{\text {er }} 21 / 89$ of 11 May 1989), it was presented a Projecto de Portaria (Draft Project Ordinance) in order to create the course in the 1991/1992 academic year. (Diário da República, 2a Série, n 174, de 31 de Julho de 1991, Pág. 7973-Figure 11). This course was created based on the following facts: national and regional necessities, opportunities and interest in his creation; matches both State and private entities requests; help to create and develop activities in main Aeronautic fields such as design, construction, operation and maintenance; promote the high technology industries establishment around the region and provide the University with adequate human and material resources owned or provided by various institutions related to aviation activity. The profile of this Licenciatura Degree (Graduation Degree) had five years duration from which the first two were basic training in Mathematics, Physics, Computer Sciences, Drawing and as well, some common disciplines to the Electrical and Mechanical Engineering. The last three years were specialized subjects

Anexo

Licenciatura em Engenharia Aeronáutica

Estrutura Curricular

1 - Área Científica do curso:

Engenharia Aeronáutica

2 - Duração normal do curso:

Cinco anos lectivos

3 - Condições necessárias à obtenção do grau:

167 unidades de crédito

4 - Áreas científicas e respectivas unidades de crédito:

4.1 - Areas científicas obrigatórias:

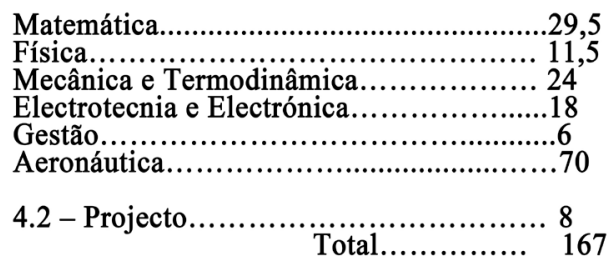

Figure 11. Main areas subjects of the Aeronautics Engineering Degree created at UBI in 1991 (excerpt of Diário da República, série II, $\left.\mathrm{n}^{\circ} 174\right)$. 
like Fabricação e Manutenção de Aeronaves (Manufacturing and Aircraft Maintenance), Projecto de Aeronaves (Aircraft Design), Operações de Aeronaves (Aircraft Operations), Gestão de Transporte Aéreo (Air Transport Management) and Segurança de Voo (Flight Safety).

The course was designed to create a vast level skills in its graduates: play roles in both technical and scientific character in the production scope; maintenance and operation in aeronautical circles; developing activities in research and development; planning the design, manufacture and operation systems related to aircraft and their operation; analyze and discuss specifications related to the supply or acquisition of aeronautical circles as well as its operation and exploration play and teaching activities at various levels within their specialty. Related to the Faculty, the disciplines responsibility had the collaboration from high skilled Portuguese Air Force technicians, from ANA-Aeroportos e Navegação Aérea (Airports and Aerial Navigation), from England Universities teachers (Loughborough University of Technology, Cranfield Institute of Technology) and from French Universities teachers (École Nationale Supérieure de L'Aéronautique et de IEspace, École Nationale Supérieure d'Ingénieures de Constructions Aeronautiques and École Nationale de I'Aviation Civile). On January 1991, in collaboration of Universidade da Beira Interior the Cranfield Institute of Technology proposed a Double Degree Programme arrangement [20]. Regarding to resources and equipment needs for the operation of Aeronautics Engineering Degree, the laboratories of common subjects between this and other already existing courses at this University (Mechanical, Mechanics of Materials, Thermodynamics, Fluid Mechanics, Analog and Digital Electronics, Electrical Engineering and Electrical Machines, Automation and Control and Thermal Machines), were with enough equipment to support the training of Aeronautical Engineers candidates students. The Aerodynamics and Flight Mechanics, Propulsion and Flight Operations laboratories were properly equipped. Laboratories had "mock-ups" to visualize the operation of different systems (engines, turbines, landing gear, instruments, etc). Airplanes were ready for demonstration of its various components and to conduct flight tests. In addition to the necessary budget funds for all Aeronautics purposes, the University had also a highly significant civil and military entities support such as the Portuguese Air Force, the ANA, the OGMA and the City Hall of Covilhã. Regarding to bibliographic material, the University Library already had a considerable number of specialty publications, and any indispensable publication could be readily available. Related with Computational needs, the University had a Computer Center that had the necessary equipment for Aeronautics circles teaching. By the Deliberação do Senado $n^{\circ}$ 26/1999, UBI created its first Master's Degree in Aerospace Systems Engineering which began operating in the academic year 1999/2000 (Figure 12).

In 1999 by the Declaração de Bolonha (June 19, 1999) the European community triggered the Bologna Process which consists to establish a European Area of Higher Education starting from the commitment of the signatory countries (originally 29 and already 47 at 2009) to promote reforms of their education systems. With the suitability 
PLANO DE ESTUDOS DO MESTRADO EM EMGENHARIA DE SISTEMAS AEROESPACIAIS

\begin{tabular}{ll}
\hline $1^{\circ}$ SEMESTRE & $>$ Controlo de Sistemas Aeroespaciais \\
(disciplinas) & $>$ Soldadura e Legislação de Materiais \\
& $>$ Dinâmica de Gases \\
& $>$ Motores \\
& $>$ Transmissão de Calor e Massa \\
\hline & $>$ Vibração e Estabilidade \\
$2^{\circ}$ SEMESTRE & $>$ Aerodinâmica, Satélites e Naves Espaciais \\
$($ disciplinas) & $>$ Dinâmica dos Fluidos Computacional \\
& $>$ Controdores e Conversores Eléctricos \\
\hline ESCOLHER UMA & Conservação de Energia e Ambiente \\
DAS SEGUINTES & Organização e Planeamento da Produção \\
OPÇÔES &
\end{tabular}

Figure 12. Subjects of the Master's Degree in Aerospace Systems Engineering created at UBI in 1999.

of the Portuguese courses to this European System, Portugal amended its Law on the Education System (Lei $n^{\circ}$ 49/2005 de 30 de Agosto) by the entry into force of Decreto-Lei 74/2006 de 24 de Março. The Academical Degrees were now based on a system of three education cycles: $1^{\text {st }}$ cycle, lasting at least three years, which confers a Licenciatura degree; $2^{\text {nd }}$ Cycle, which lasts one year and a half to two years (exceptionally one year), which confers a Mestrado degree, and $3^{\text {rd }}$ cycle, which confers a $\mathrm{PhD}$ degree. The 5 years Degree is recognized by the Ordem dos Engenheiros (Professional Association of Engineers) since 2001. From 2008 to 2011, UBI decided to implement a 3-year Licenciatura em Engenharia Aeronáutica diploma followed by a 2-year Mestrado em Engenharia Aeronáutica. This 5 years Degree was also recognized by the Ordem dos Engenheiros. From 2011/2012 onwards, UBI decided to implement a 5-year Mestrado Integrado em Engenharia Aeronáutica during which (after the first 3 years) a Licenciatura em Engenharia Aeronáutica diploma is also given. The UBIs Aeronautics Engineering students by 2010 were the only ones in Europe to organize an annual scope Air Festival (with organization exclusively composed by students).

\subsection{AFA: Aeronautics Engineering Course at Academia Da Força Aérea}

In 1991 another Aeronautics Engineering Degree started at Portugal, at Academia da Força Aérea (Air Force Academy). By the Decreto-Lei $n^{\circ}$ 27/78 de 27 de Janeiro de 1978 it was created the Academia da Força Aérea higher education institution designed to graduate permanent staff of the Portuguese Air Force officers and to provide courses with interest for the development of Aeronautical knowledge at national level. These courses provided aimed mainly the officers' training for the Piloto Aviador (Pilot Aviator), 
Engenheiros Aeronáuticos (Aeronautical Engineers), Engenheiros Electrotécnicos (Electrical Engineers) and Engenheiros de Aeródromos (Airfields Engineers) and other specialties to be determined by order of the Chief of Staff of the Air Force. The faculty was composed by university professors or individuals with a military or civilian college and proven competence in the field of their respective disciplines. The Academia da Força Aérea began operating in February 1, 1978 with the $3^{\text {rd }}$ year of the Air Force course of Piloto Aviador (Diário da República, Série I, No. 23, Decreto-Lei No. 27/78, VI, $A r t^{\circ} 25^{\circ}$ ). In 1991/92 the Portuguese Air Force Academy started his own Degree in Aeronautics Engineering. Such as happened before in the Portuguese Air Force Aeronautics Engineering Degree (from 1963 to 1974) the Air Force Academy gives basic training for three years to their future Aeronautics Engineers and then sends them to IST for the last three years. Figure 13 illustrates the subjects of the Aeronautics Engineering Military Master Degree at Academia da Força Aérea.

The Air Force Academy lasts 6 years, because, due to an inclusion of Tirocínio (Apprenticeship), an internship planned and coordinated by the Academy in connection with several Agencies/Departments of the Portuguese Air Force, whose duration varies

\begin{tabular}{|c|c|}
\hline $1^{\circ}$ Ano Académico & $2^{\circ}$ Ano Académico \\
\hline $\begin{array}{l}\text { Álgebra Linear } \\
\text { Cálculo Diferencial e Integral I } \\
\text { História Militar e Aviação Militar } \\
\text { Legislação Militar } \\
\text { Língua Inglesa (STANAG } 600 \text { 1; CEF) } \\
\text { Programação } \\
\text { Psicologia Militar } \\
\text { Cálculo Diferencial e Integral II } \\
\text { Desenho e Modelação Geométrica } \\
\text { Ética e Deontologia Militar } \\
\text { Língua Inglesa (STANAG } 600 \text { 1; 2-2-2-1; CEF) } \\
\text { Metodologia e Comunicação } \\
\text { Orientação Topográfica e Cartas Militares } \\
\text { Química }\end{array}$ & $\begin{array}{l}\text { Análise Complexa e Equações Diferenciais } \\
\text { Direito Militar } \\
\text { Gestão } \\
\text { Língua Inglesa (STANAG } 6001 \text {; CEF) } \\
\text { Matemática Computacional } \\
\text { Mecânica e Ondas } \\
\text { Electromagnetismo e Óptica } \\
\text { Língua Inglesa (STANAG } 600 \text { 1; 2-2-2-1; CEF) } \\
\text { Operações Aéreas } \\
\text { Operações Conjuntas e Combinadas } \\
\text { Probabilidades e Estatística } \\
\text { Sistemas Digitais } \\
\text { Sociologia Militar }\end{array}$ \\
\hline $3^{\circ}$ Ano Académico & $4^{\circ}$ Ano Académico \\
\hline $\begin{array}{l}\text { Mecânica dos Fluidos } \\
\text { Ciências dos Materiais } \\
\text { Introdução às Relações Internacionais } \\
\text { Língua Inglesa (STANAG } 600 \text { 1; CEF) } \\
\text { Mecânica Aplicada I } \\
\text { Organização das Forças Armadas } \\
\text { Segurança e Prevenção de Acidentes } \\
\text { Termodinâmica } \\
\text { Comando e Liderança } \\
\text { Desempenho de Aeronaves } \\
\text { Língua Inglesa (STANAG } 600 \text { 1; 3-2-3-2; CEF) } \\
\text { Logística Militar } \\
\text { Mecânica Aplicada II } \\
\text { Aerodinâmica I } \\
\text { Defesa Nuclear, Radiologia Biológica e Química }\end{array}$ & $\begin{array}{l}\text { Arquitectura de Computadores } \\
\text { Helicópteros } \\
\text { Estabilidade de Voo } \\
\text { Introdução ao Controlo } \\
\text { Instrumentação } \\
\text { Circuitos Eléctricos e Introdução á Electrónica } \\
\text { Controlo de Voo } \\
\text { Ensaios de Voo } \\
\text { Mecânica dos Materiais } \\
\text { Sistemas Eléctricos e Electromecânicos }\end{array}$ \\
\hline $5^{\circ}$ Ano Académico & $6^{\circ}$ Ano Académico \\
\hline $\begin{array}{l}\text { Aerodinâmica II } \\
\text { Mecânica Computacional } \\
\text { Mecânica dos Sólidos } \\
\text { Termodinâmica II } \\
\text { Vibrações e Ruído } \\
\text { Gestão de Projectos de Engenharia } \\
\text { Mecânica Estrutural } \\
\text { Transmissão de Calor } \\
\text { Orgãos de Máquinas } \\
\text { Processos de Ligação } \\
\text { Mecânica de Fluidos Computacional } \\
\text { Tecnologia Mecânica }\end{array}$ & $\begin{array}{l}\text { Comportamento Mecânico dos Materiais } \\
\text { Estruturas Aeroespaciais } \\
\text { Propulsão } \\
\text { Projecto Aeroespacial } \\
\text { Materiais Compósitos e Laminados } \\
\text { Dissertação de Mestrado ou Trabalho de } \\
\text { Projecto }\end{array}$ \\
\hline
\end{tabular}

Figure 13. Subjects of the Aeronautics Engineering Military Master's Degree at Academia da Força Aérea (2008/2009). 
from 6 to 13 months, and is designed to teach different technical professionals skills to their students, not included in the Degrees programs, but considered essentials to the future performance of the new functions of the Permanent Officers (QP). The Aeronautics Engineers officers of the Portuguese Air Force functions, competences and their specialty activities are within military scope, including Project, Technical Management and Aircrafts Logistics and Weapon Systems, Engines and Mechanical Systems, including the elaboration of studies to support the Aircrafts Operation and Maintenance.

\subsection{IST: Aeronautics Engineering Course at Instituto Superior Técnico}

In 1992, the Instituto Superior Técnico began its Aerospace Engineering Degree. The first steps leading to IST were taken by the Queen D. Maria II in Royal Decree $30 \mathrm{De}$ cember 1852 with the creation of the Instituto Industrial de Lisboa (Lisbon Institute of Industry). In 1869 and by the Escola Comercial addition (Commercial School) it was renamed Instituto Industrial e Comercial de Lisboa (Industrial and Commercial Institute of Lisbon). By the Diário do Governo, Série I, $n^{\circ} 121$ de 25 de Maio de 1911, Instituto Superior Técnico (IST) was created from the disaggregation of the Industrial and Commercial Institute of Lisbon. Nevertheless, the Aerospace/Aeronautics Engineering civil Degree at IST has started only in 1992 as a result of many experience initiatives in the scope of AGARD-Advisory Group for Aerospace Research and Development of NATO (presently NATO RTO-Research and Technology Organization). In the AGARD $14^{\text {th }}$ General Assembly that took place in Lisbon, Portugal, 16-17 of September 1964, greetings were presented by the Chief of Staff, Portuguese Air Force, General Corte-Real. "He looked forward to increasing cooperation with AGARD, and mentioned that in the past Portuguese participation in AGARD affairs had been handicapped by the fact that even the Portuguese Air Force had to send their engineers abroad for aeronautical training. Now, with the help of the AGARD Consultant and Exchange Programme, a course in Aeronautical Engineering had been established at the Lisbon Technical Institute, under Air Force sponsorship, and with support from the Ministry of Education". The Aerospace Engineering Degree was created by the Deliberação do Senado ${ }^{\circ}$ 13/UTL/92 and published at Diário da República, Série II, $n^{\circ} 138$ de 17 de Junho de 1992 -Figure 14. Initially, this course was projected with two different branches: Aircraft and Avionics (Figure 12). His subjects were based on the cooperation between Mechanical Engineering and Electrical Engineering Departments. This Degree is coordinated by the Aerospace Mechanics structure section, formed with staff from the Mechanical Engineering Department. This Aerospace Mechanics structure is responsible for the teaching of all the Flight Mechanics and Aerospace Design Subjects. The Department of Mechanical Engineering is also responsible for Applied Thermodynamics Section, Systems Section, Mechanical Project Section and Production Section. The Department of Electronical and Computers Engineering is responsible for Electronics, Telecommunications, Electric Machines, Energy, Digital Systems and Radiations, Control Systems, Propagation and Radiation and Electric Measurements and Technology. Other five Departments complete the cooperation: Mathematical, Economics 
Anexo à deliberação do Senado no 23/UTL/92

1 - Área Científica do curso - Engenharia Aeronáutica

2 - Duração normal do curso - cinco anos lectivos

3 - Número total de unidades de crédito necessário à concessão do grau -200

4 - Áreas científicas e distribuição das unidades de crédito:

4.1 - Áreas científicas obrigatórias:

Áreas

Matemática..................................

Física e Química.

Computação.

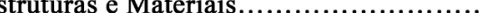

Aerodinâmica e Propulsão.

Sistemas e Controlo

Sistemas Digitais.

Economia e Gestão.

4.2 - Áreas científicas optativas -8 créditos

4.2.1 - Ramo de Aeronaves:

Estruturas e Materiais;

Aerodinâmica e Propulsão;

Aeroespacial;

Computação;

Sistemas Digitais;

Sistemas e Controlo

Economia e Gestão

\subsection{2 - Ramo de Aviónica:}

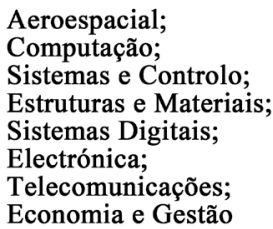

Figure 14. Main areas subjects of the Aerospace Engineering Degree created at IST in 1992 (excerpt of Diário da República, série II, $\mathrm{n}^{\circ}$ 138).

Management, Materials, Physics and Chemistry. Since March 2004, IST is a member of PEGASUS-Partnership [21] of a European Group of Aeronautics and Space Universities. PEGASUS was founded in 1998 in Toulouse, France and is open to all EU institutions providing a sufficiently qualified education in AS engineering (e.g.: Bac + 5 curricula with a well-balanced blend of subjects, education combined with research). Due of the Bologna Process, and by the Despacho $n^{\circ} 1374 / 2007$ do Diário da República, $2^{a}$ Série, $n^{\circ}$ 20, de 29 de Janeiro, Art $^{\circ} 1^{\circ}$, the IST has adapted the Aerospace Engineering course with a Licenciatura in Sciences in Aerospace Engineering Degree (3 years) and with a Mestrado degree in Aerospace Engineering. In 2008, by the Despacho $n^{\circ}$

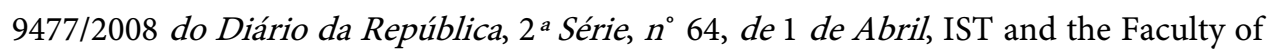
Aerospace Engineering of Delft University of Technology (TUDelft) started to offer a Double Degree master program Flight Dynamics \& Control and Avionics (as of September 2008). This Double Degree allows students to carry out their $7^{\text {th }}$ and $8^{\text {th }}$ semester's studies at IST and the $9^{\text {th }}$ and $10^{\text {th }}$ semesters at TUDelft or $7^{\text {th }}$ and $8^{\text {th }}$ semester's studies at TUDelft and the $9^{\text {th }}$ and $10^{\text {th }}$ semesters at IST. This Double Degree program is an 
international profile program of the Master track Dynamics and Control of Aerospace Vehicles. The double degree program is open to BSc graduates in Aerospace Engineering of TUD, IST and Pegasus-Universities. Top class students from other universities might also be admitted. In 2009, by the Despacho $n^{\circ}$ 19046/2009 do Diário da Repúbli-

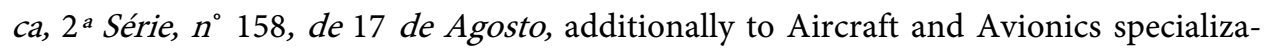
tions, the course opens its third branch: a Space specialization. By the Despacho $n^{o}$ 19293/2010, do Diário da República, 2a Série, $n^{\circ}$ 251, de 29 de Dezembro, The PEGASUS Partner IST Lisbon decided to implement a 5-year Mestrado Integrado em Engenharia Aeroespacial during which (after the first 3 years) a Licenciatura em Ciências de Engenharia Aeroespacial diploma is also given. This Mestrado Degree is recognized by the Ordem dos Engenheiros (Professional Association of Engineers) and by the Fundação das Universidades Portuguesas (Foundation of Portuguese Universities). Today, several Portuguese companies participating actively in ESA and EADS, such OGMA, TAP Air Portugal, EFACEC, Edisoft, Skysoft, Critical Software, Deimos Engenharia, LusoSpace, Omnidea, UAVision and Embraer Portugal. Many UBI and IST students hold prominent positions in these companies, as well as in larger companies, such as ESA, Eurocontrol, Airbus Industries, British Aerospace, Daimler-Chrysler, Astrium, Rolls-Royce, and Snecma

\section{Conclusion}

After all the initial excitement caused by the airplane appearance, in 1922 two Portuguese airmen managed to held the First Crossing of the South Atlantic, a Journey that also became known as the first Air Journey exclusively made with the help of scientific instruments: an adapted sextant and a path corrector. This fact was a Portuguese proud and led the Portuguese History to record about 30 equally long journeys made by many Portuguese pilots, mostly military, and above all, two Circum-navigation Flight Attempts. In the 1930 s, under license, Portugal began producing the Bristol "Jupiter" and the Gnôme \& Rhône engines as well as the aircrafts Potez XXV, Vickers Valparaiso and the Pou-du Ciel at the OGMA. In the 1950s the Air Force Quadros Superiores formation needs and the OGMA evolution, led Portugal to recruit staff in order to graduate Aeronautics engineers on several countries. In $1960 \mathrm{~s}$ the first Aeronautics Engineering Military Degree was created in conjunction with IST. In 1991 the first Aeronautics Engineering Civil Degree was created at UBI. In the same year the Academia da Força Aérea stars its own Aeronautics Engineering Military Degree and in 1992 the IST started its Aerospace Engineering Degree. In 2007, these Civil Degrees were adapted to Bologna Process (1999). The creation of these courses had a very positive impact on Portuguese society, with the creation of several small companies related to Aeronautics and Space subjects. Some of these companies participate actively in the European projects of ESA and EADS.

\section{Acknowledgements}

The present work was performed in the scope of the activities of the AeroG-Aeronautics 
and Astronautics Research Center (http://aeronautics.ubi.pt). The financial support of the Portuguese Ministry of Science through the Science and Technology Foundation (FCT) is gratefully acknowledged.

\section{References}

[1] Cardoso, E.P.C. (1981) História da Força Aérea Portuguesa, Vol. II, Edição Cromocolor, Lda, Lisboa, Printed in Gratelo, SARL, 2700 Amadora.

[2] Barata, J.M.M., Neves, F.M.S.P. and Silva, A.R.R. (2011) The History of Aviation Education and Training. Proceedings of the 49 th AIAA Aerospace Sciences Meeting including the New Horizons Forum and Aerospace Exposition, Orlando, 4-7 January 2011, 5460-5465. http://arc.aiaa.org/doi/abs/10.2514/6.2011-407 http://dx.doi.org/10.2514/6.2011-407

[3] Barata, J.M.M., Neves, F.M.S.P. and Silva, A.R.R. (2012) The History of Aerospace/Aeronautics Engineering in Portugal, Proceedings of the 50th AIAA Aerospace Sciences Meeting including the New Horizons Forum and Aerospace Exposition, Nashville, 9-12 January 2012, 14119-14130. http://arc.aiaa.org/doi/abs/10.2514/6.2012-954 http://dx.doi.org/10.2514/6.2012-954

[4] Silva, A.R.R., Morgado, C.M.P., Barata, J.M.M. and Neves, F.M.S.P. (2009) First Flight from Europe to the South Atlantic-Gago Coutinho and Sacadura Cabral. Proceedings of the 47 th AIAA Aerospace Sciences Meeting and the New Horizons Forum and Aerospace Exhibit, Orlando, 5-8 January 2009, 13670-13676.

http://arc.aiaa.org/doi/abs/10.2514/6.2009-1162 http://dx.doi.org/10.2514/6.2009-1162

[5] Barata, J.M.M., Mendes, A.L.M., Morgado, C.M.P., Neves, F.M.S.P. and Silva, A.R.R. (2009) The Origins of Scientific Aircraft Navigation. Proceedings of the 45th AIAA/ASME/ SAEl ASEE Joint Propulsion Conference \& Exhibit, Denver, 2-5 August 2009, 1974-1980. http://arc.aiaa.org/doi/abs/10.2514/6.2009-5022 http://dx.doi.org/10.2514/6.2009-5022

[6] Neves, F.M.S.P., Barata, J.M.M. and Silva, A.R.R. (2010) Gago Coutinho and the Aircraft Navigation. Proceedings of the 48th AIAA Aerospace Sciences Meeting Including the Horizons Forum and Aerospace Exposition, Orlando, 4-7 January 2010, 1823-1832. http://arc.aiaa.org/doi/abs/10.2514/6.2010-156 http://dx.doi.org/10.2514/6.2010-156

[7] Neves, F.M.S.P., Barata, J.M.M. and Silva, A.R.R. (2010) Sacadura Cabral and the Dawn of Aviation. Open Journal of Applied Sciences, 6, 16-30. http://dx.doi.org/10.4236/ojapps.2016.61003

[8] Neves, F.M.S.P., Barata, J.M.M. and Silva, A.R.R. (2015) The First Aerial Raid from Portugal to Macau. Proceedings of the 53rd Aerospace Sciences Meeting, Kissimmee, 5-9 January 2015, 966-978. http://arc.aiaa.org/doi/abs/10.2514/6.2015-0103 http://dx.doi.org/10.2514/6.2015-0103

[9] Neves, F.M.S.P., Barata, J.M.M. and Silva, A.R.R. (2016) First Aerial South Atlantic Night Crossing. Advances in Historical Studies, 5, 19-35. http://dx.doi.org/10.4236/ahs.2016.51003

[10] Flight-Official Organ of the Royal Aero Club of the United Kingdom (1927) The 4th International Air Congress, No. 986, Vol. 19, 17 November 1927, 800.

[11] Flight-Official Organ of the Royal Aero Club of the United Kingdom (1930) Civil Aviation in Portugal, No. 1126, Vol. 22, 25 July 1930, 850.

[12] Flight-Official Organ of the Royal Aero Club of the United Kingdom (1930) Aero Industry 
in Portugal, No. 1233, Vol. 24, 12 August 1932, 760-761.

[13] Flight-Official Organ of the Royal Aero Club of the United Kingdom (1934) Portuguese Air Mails, No. 1353, Vol. 26, 29 November 1934, 1285.

[14] Flight-Official Organ of the Royal Aero Club of the United Kingdom (1934) OPENING THE LISBON-TANGIER SERVICE Ceremonials at Alverca Aerodrome, Lisbon: A Link with Air France, No. 1352, Vol. 26, 22 November 1934, 1268.

[15] Flight-Official Organ of the Royal Aero Club of the United Kingdom (1935) Lisbon Stages an Aero Show: A Mixed but Interesting Collection of Ancient and Modern Exhibits, No. 1381, Vol. 27, 13 June 1935, 638.

[16] Gomes, V. (2007) Portugal In Space. Acta Astronautica, 61, 526-533. http://dx.doi.org/10.1016/j.actaastro.2007.01.060

[17] http://radioamadores.net/patrono rad CT1UX.htm

[18] https://www.fct.pt/apoios/cooptrans/espaco/docs/Impact Study Portuguese Participation \%20in ESA.pdf

[19] Van der Bliek, J. (1999) The Agard History 1952-1997. 5th Edition, NATO Research and Technology Organization RTO.

[20] Proposta de Criação da Licenciatura em Engenharia Aeronáutica (1991) Universidade da Beira Interior.

[21] PEGASUS (2009) Aerospace Engineering Programmes "Ensuring Quality in European Aerospace Engineering Education" Partnership of a European Group of Aeronautics and Space Universities, 10th Anniversary, 3rd Edition.

Submit or recommend next manuscript to SCIRP and we will provide best service for you:

Accepting pre-submission inquiries through Email, Facebook, LinkedIn, Twitter, etc.

A wide selection of journals (inclusive of 9 subjects, more than 200 journals)

Providing 24-hour high-quality service

User-friendly online submission system

Fair and swift peer-review system

Efficient typesetting and proofreading procedure

Display of the result of downloads and visits, as well as the number of cited articles

Maximum dissemination of your research work

Submit your manuscript at: http://papersubmission.scirp.org/

Or contact ojapps@scirp.org 